\title{
Comment to: non-specific complaints at emergency department presentation result in unclear diagnoses and lengthened hospitalization: a prospective observational study
}

\author{
Roland Bingisser ${ }^{*}$ and Christian $\mathrm{H}$ Nickel
}

Keywords: Nonspecific complaints, Non-specific, Emergency department, Mortality, Geriatric emergency medicine

We would like to congratulate Sauer et al. for their study on the outcomes in patients presenting with nonspecific complaints (NSC) [1] and would like to comment on certain aspects of their publication.

First, the definition of NSC may be discussed controversially [2]. The authors used our original definition [3] and showed a near perfect inter-rater agreement with a kappa of 0.9 when retrospectively classifying symptoms to be specific or nonspecific. Therefore, post-hoc classification can be questioned to be truly prospective, as the data were obtained previously, and the raters were not blinded to outcomes or diagnoses. However, the authors showed impressively that this definition of NSC appears to be reliable and reproducible.

Second, the statement that "prospective comparisons of the outcomes of emergency patients with nonspecific complaints versus specific complaints are lacking" needs clarification. Taking a positive definition of NSC (on the basis suggested by Bhalla [4]), we have previously shown in a consecutive sample of 3960 ED visits [5] that "generalized weakness", the most prevalent nonspecific symptom, [3] has serious outcomes; namely significantly increased hospitalization, ICU admission, in-hospital, and 1-year mortality, as compared to specific complaints. Therefore, direct previous prospective comparisons between NSC and other complaints have shown deleterious outcomes irrespective of the rule-out $[3,6]$ or

* Correspondence: roland.bingisser@usb.ch

Department of Emergency Medicine, University Hospital Basel, Petersgraben 2, $\mathrm{CH}-4031$ Basel, Switzerland

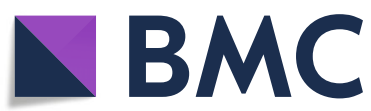

(c) The Author(s). 2018 Open Access This article is distributed under the terms of the Creative Commons Attribution 4.0 International License (http://creativecommons.org/licenses/by/4.0/) which permits unrestricted use, distribution, and reproduction in any medium, provided you give appropriate credit to the original author(s) and the source, provide a link to the Creative Commons license, and indicate if changes were made. The Creative Commons Public Domain Dedication waiver (http://creativecommons.org/publicdomain/zero/1.0/) applies to the data made available in this article, unless otherwise stated. rule-in $[4,7]$ definitions of NSC [5]. This is in agreement with previous retrospective studies as well $[8,9]$.

Third, the most important difference between the BANC cohort and Sauter's cohort was the patient inclusion procedure. While Karakoumis [10] prospectively included 1300 patients presenting with NSC in a multi-centre setting, Sauter included 165 patients hospitalized in a single centre.

Taken together, in spite of major differences in the inclusion process and the definitions used, outcomes in patients with NSC from most studies are similar. Several prospective studies now prove this fact.

\section{Competing interests}

The authors declare that they have no competing interests.

\section{Publisher's Note}

Springer Nature remains neutral with regard to jurisdictional claims in published maps and institutional affiliations.

Received: 21 September 2018 Accepted: 24 September 2018

Published online: 19 November 2018

\section{References}

1. Sauter TC, Capaldo G, Hoffmann M, Birrenbach T, Hautz SC, Kammer JE, et al. Non-specific complaints at emergency department presentation result in unclear diagnoses and lengthened hospitalization: a prospective observational study. Scand J Trauma Resusc Emerg Med. 2018;26(1):60.

2. Kellett J, Nickel $\mathrm{CH}$. What are nonspecific complaints and what are their causes and outcomes? The common unknown unknowns of medicine. Eur Intern Med. 2018:47:e12-e3.

3. Nemec M, Koller MT, Nickel CH, Maile S, Winterhalder C, Karrer C, et al. Patients presenting to the emergency department with non-specific complaints: the Basel non-specific complaints (BANC) study. Acad Emerg Med. 2010;17(3):284-92. 
4. Bhalla MC, Wilber ST, Stiffler KA, Ondrejka JE, Gerson LW. Weakness and fatigue in older ED patients in the United States. Am J Emerg Med. 2014; 32(11):1395-8,

5. Bingisser R, Dietrich M, Nieves Ortega R, Malinovska A, Bosia T, Nickel CH. Systematically assessed symptoms as outcome predictors in emergency patients. Eur J Intern Med. 2017:45:8-12

6. Nickel CH, Messmer AS, Geigy N, Misch F, Mueller B, Dusemund F, et al. Stress markers predict mortality in patients with nonspecific complaints presenting to the emergency department and may be a useful risk stratification tool to support disposition planning. Acad Emerg Med. 2013; 20(7):670-9.

7. Nickel $\mathrm{CH}$, Malinovska A, Bingisser R. Should weakness be subsumed to nonspecific complaints?-correspondence in response to Bhalla et al. Am J Emerg Med. 2015;33(5):722-3.

8. Safwenberg $U$, Terent $A$, Lind $L$. The emergency department presenting complaint as predictor of in-hospital fatality. Eur J Emerg Med. 2007; 14(6):324-31.

9. Djarv T, Castren M, Martenson L, Kurland L. Decreased general condition in the emergency department: high in-hospital mortality and a broad range of discharge diagnoses. Eur J Emerg Med. 2015;22(4):241-6.

10. Karakoumis J, Nickel CH, Kirsch M, Rohacek M, Geigy N, Muller B, et al. Emergency presentations with nonspecific complaints-the burden of morbidity and the Spectrum of underlying disease: nonspecific complaints and underlying disease. Medicine (Baltimore). 2015;94(26):e840.

Ready to submit your research? Choose BMC and benefit from:

- fast, convenient online submission

- thorough peer review by experienced researchers in your field

- rapid publication on acceptance

- support for research data, including large and complex data types

- gold Open Access which fosters wider collaboration and increased citations

- maximum visibility for your research: over $100 \mathrm{M}$ website views per year

At $\mathrm{BMC}$, research is always in progress.

Learn more biomedcentral.com/submissions 